\title{
Correction to: An optimised CRISPR/ Cas9 protocol to create targeted mutations in homoeologous genes and an efficient genotyping protocol to identify edited events in wheat
}

Xiucheng Cui 1,2, Margaret Balcerzak1, Johann Schernthaner ${ }^{1}$, Vivijan Babic ${ }^{3}$, Raju Datla ${ }^{3}$, Elizabeth K. Brauer ${ }^{1}$, Natalie Labbé ${ }^{1}$, Rajagopal Subramaniam ${ }^{1}$ and Thérèse Ouellet ${ }^{1 *}$ (1)

\section{Correction to: Plant Methods (2019) 15:119}

https://doi.org/10.1186/s13007-019-0500-2

In the original publication [1], the copyright line was incorrectly published as "๑ The Author(s) 2019". The corrected copyright line should read as " $\odot$ Her Majesty the Queen in Right of Canada as represented by the Minister of Agriculture and Agri-Food Canada, 2019". The original article has been corrected.
Reference

1. Cui X, Balcerzak M, Schernthaner J, Babic V, Datla R, Brauer EK, Labbé N, Subramaniam R, Ouellet T. An optimised CRISPR/Cas9 protocol to create targeted mutations in homoeologous genes and an efficient genotyping protocol to identify edited events in wheat. Plant Methods. 2019;15:119. https://doi.org/10.1186/s13007-019-0500-2.

\section{Publisher's Note}

Springer Nature remains neutral with regard to jurisdictional claims in published maps and institutional affiliations.

\author{
Author details \\ 1 Ottawa Research and Development Centre, 960 Carling Avenue, Ottawa, ON \\ K1A 0C6, Canada. ${ }^{2}$ Department of Biology, University of Ottawa, 75 Laurier \\ Ave E, Ottawa, ON K1N 6N5, Canada. ${ }^{3}$ Aquatic and Crop Resource Develop- \\ ment, National Research Council Canada, 110 Gymnasium Place, Saskatoon, SK \\ S7N 0W9, Canada.
}

Published online: 30 December 2019
The original article can be found online at https://doi.org/10.1186/s1300 7-019-0500-2.

*Correspondence: therese.ouellet@canada.ca

${ }^{1}$ Ottawa Research and Development Centre, 960 Carling Avenue, Ottawa, ON K1A 0C6, Canada

Full list of author information is available at the end of the article

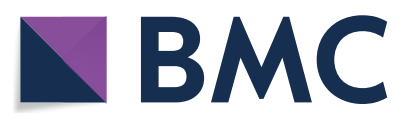

(c) Her Majesty the Queen in Right of Canada as represented by the Minister of Agriculture and Agri-Food Canada 2019. This article is licensed under a Creative Commons Attribution 4.0 International License, which permits use, sharing, adaptation, distribution and reproduction in any medium or format, as long as you give appropriate credit to the original author(s) and the source, provide a link to the Creative Commons licence, and indicate if changes were made. The images or other third party material in this article are included in the article's Creative Commons licence, unless indicated otherwise in a credit line to the material. If material is not included in the article's Creative Commons licence and your intended use is not permitted by statutory regulation or exceeds the permitted use, you will need to obtain permission directly from the copyright holder. To view a copy of this licence, visit http://creativecommons.org/licenses/by/4.0/. The Creative Commons Public Domain Dedication waiver (http://creativecommons.org/publicdomain/zero/1.0/) applies to the data made available in this article, unless otherwise stated in a credit line to the data. 